\title{
The Effect of Organizational Culture and Information Technology on Employee Performance with Employee Satisfaction as a Mediator in The Electronic Court System (E-Court) in District Court of Sleman, Yogyakarta
}

\author{
Muhammad Luthfi Hendrato ${ }^{1, *}$ Arief Subyantoro ${ }^{1}$ Wisnalmawati ${ }^{1}$ \\ ${ }^{1}$ Yogyakarta Veteran National Development University, Indonesia \\ *Corresponding author. Email: $\underline{\text { luthfihendrato28@gmail.com }}$
}

\begin{abstract}
This study aims to determine the effect of organizational culture and information technology on employee performance with job satisfaction as a mediator in the electronic court system (e-Court) in the District Court of Sleman, Yogyakarta. This study uses a census method with a correlation or explanatory type of research that examines the relationship between variables. The results are then analyzed to provide recommendations for government agencies of law, especially in the District Court. The results revealed a positive and significant impact of organizational culture and job satisfaction on employee performance. Information technology has a positive and significant impact on job satisfaction. Employee performance is influenced by organizational culture and information technology through job satisfaction. Organizational culture and information technology in the District Court of Sleman have a positive effect on employee performance with job satisfaction as a mediator. This research is also useful as a basis for further research related to information technology in the realm of law.
\end{abstract}

Keywords: Organizational culture, information technology, job satisfaction, employee performance.

\section{INTRODUCTION}

Organizational culture is a system of meanings and beliefs that are shared within the organization and is a reference for action and differentiating between organizations. The research results [1] show that organizational culture has a positive influence and has a significant relationship to employee performance through job satisfaction as a mediator. Job satisfaction is an individual's point of view regarding his job where there is or does not occur a meeting point between the value of remuneration for employees of the organization and the level of remuneration that is desired by the employee [2]. An employee's job satisfaction will have an impact on his/her performance [3].

Indonesia has now entered the digital era where work is not only done manually but is also done using technology. Information technology is a technology that is used to process data in various ways to produce quality information that is relevant, accurate, and timely so that it can be used for government in decision making [4]. Research [5] states that information technology influences employee performance with job satisfaction as a mediator. Performance satisfaction can be a mediating variable that affects other elements in workplaces such as organizational culture, information technology, and employee performance.

E-Court or electronic justice is a breakthrough of the Supreme Court in the field of electronic-based court service administration that utilizes information technology (IT) based on Supreme Court Regulation Number 3/2018 on Case Administration in Electronic Courts. The issuance of this law followed by the launch of the E-Court application has opened space for the electronic case registration process (e-filing) for electronic payment of court fees (e-payment), summons, and notifications to the parties electronically (esummons). This is done to realize simple judicial services, fast, and low cost as well as to keep up with the 
demands and the times as well as the fast and efficient administration of justice services.

The court that has been running the administration of electronic-based court services or e-court since January 2020 is the District Court of Sleman. However, the implementation of this E-Court has not yet been implemented completely. The success of this electronicbased justice service administration system will depend on the understanding, readiness, and ability of employees to adapt to change. Changes in organizational forms, changes in culture, as well as the application of internal and external regulations such as the application of the provisions of the code of conduct direct employees to the service of good governance. Strategic steps also need to be taken including information technology qualifications in developing job competency standards, developing functional positions for computer institutions, developing information technology governance.

\section{RESEARCH METHODS}

\section{Research design}

This research uses quantitative research methods. The research emphasizes its analysis of numerical data (numbers) processed by statistical methods [6]. This type of research is a correlation or explanatory research which examines the relationship between variables. This study consists of four variables, namely the variable organizational culture and information technology as the independent variable (independent variable), the job satisfaction variable as the mediating variable, and the employee performance variable as the dependent variable (dependent variable).

\section{Research Site}

The research was carried out in the District Court of Sleman, which is located on Jalan KRT. Pringgodiningrat No.1 Beran, Sleman.

\section{Research Sample}

The number of samples were determined using the census method referring to [7] which states that saturated sampling is a sampling technique when all members of the population are used as samples. Another term for a saturated sample is a census. So that the number of samples determined in this study were all 60 employees in the District Court of Sleman, Yogyakarta.

\section{Data Analysis}

Data processing in this study uses the SPSS for Windows program.

\section{RESEARCH RESULT}

From 60 research respondents in the District Court of Sleman, the following data were obtained:

\section{Respondent Characteristics}

Furthermore, the results of the data quality test, namely the validity test, showed that all question items had a value of $r_{\text {count }}>r_{\text {table }}$ and a significance of $<0.05$; so that the data was considered valid.

Reliability test shows all variables have value Cronbach Alpha >0.6; so that all data have good reliability.

Furthermore, the test results of the effect of organizational culture on job satisfaction and employee performance are as follows:

\begin{tabular}{|c|c|c|c|l|l|}
\hline No. & $\begin{array}{c}\text { Test } \\
\text { Description }\end{array}$ & $\begin{array}{c}\text { Compute } \\
\text { Statistics }\end{array}$ & $\begin{array}{c}\text { Table } \\
\text { Statistics }\end{array}$ & Decision & Information \\
\hline 1 & $\begin{array}{c}\mathrm{X} 1 \mathrm{Z} \\
\text { Hol: } \mathrm{pl}=0 \\
\text { Hal: } \mathrm{pl} \neq 0\end{array}$ & $t=11,094$ & $t=2.0024$ & Reject Ho1 & $\begin{array}{l}\text { X1 has a positive and } \\
\text { significant effect on Z }\end{array}$ \\
\hline 2 & $\begin{array}{c}\mathrm{Xl} \mathrm{Y} \\
\text { Ho3: } \mathrm{pl}=0 \\
\text { Ha3: } \mathrm{pl} \neq 0\end{array}$ & $t=8,252$ & $t=2.0024$ & Reject Ho3 & $\begin{array}{l}\text { X1 has a positive and } \\
\text { significant effect on Y }\end{array}$ \\
\hline 3 & $\begin{array}{c}\mathrm{YZ} \\
\text { Ho5: } \mathrm{pl}=0 \\
\text { Ha5: } \mathrm{pl} \neq 0\end{array}$ & $t=16,864$ & $t=2.0024$ & Reject Ho5 & $\begin{array}{l}\text { Z has a positive and } \\
\text { significant effect on Y }\end{array}$ \\
\hline
\end{tabular}

The table above shows a summary of all statistical hypotheses used in this study and the results of their testing. Test number 1 shows that the results of testing on the effect of organizational culture (X1) on job satisfaction $(Z)$ are significant, while test number 2 shows that the influence of organizational culture (X1) is significant on employee performance $(\mathrm{Y})$. Test number 3 shows that the effect of Job Satisfaction (Z) on employee performance $(\mathrm{Y})$ is significant.

The testing on the effect of organizational culture on employee performance with job satisfaction as a mediator shows significant results as follows:

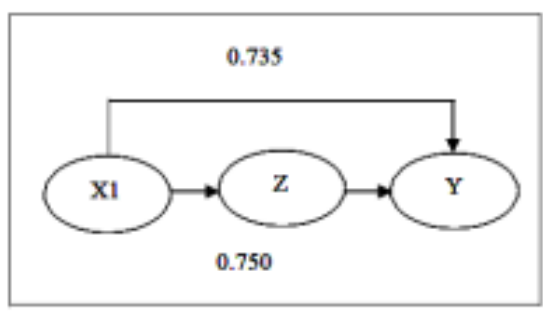

The direct effect of organizational culture on employee performance in the District Court of Sleman was 0.735 , while the indirect effect of organizational culture on the performance of employees in the District Court of Sleman (with Job Satisfaction as a mediating variable) was 0.750 . The direct effect of organizational culture on employee performance in the District Court of Sleman was smaller than the indirect effect.

Furthermore, the results of testing on the effect of information technology on job satisfaction and employee performance are as follows: 


\begin{tabular}{|c|c|c|c|c|c|}
\hline No. & $\begin{array}{c}\text { Test } \\
\text { Description }\end{array}$ & $\begin{array}{c}\text { Compute } \\
\text { Statistics }\end{array}$ & $\begin{array}{c}\text { Table } \\
\text { Statistics }\end{array}$ & Decision & lnformation \\
\hline 1 & $\begin{array}{c}\mathrm{X} 2 \mathrm{Z} \\
\mathrm{H} 02: \mathrm{pl}=0 \\
\mathrm{Hn} 2: \mathrm{pl} \neq 0\end{array}$ & $t=9,674$ & $t=2.0024$ & Reject Ho2 & $\begin{array}{l}\text { X2 has a positive and } \\
\text { significant effect on Z }\end{array}$ \\
\hline 2 & $\begin{array}{c}\mathrm{X} 2 \mathrm{Y} \\
\mathrm{Ho4}: \mathrm{pl}=0 \\
\mathrm{Ha4}: \mathrm{pl} \neq 0\end{array}$ & $t=7,657$ & $t=2.0024$ & Reject Ho4 & $\begin{array}{l}\text { X2 has a positive and } \\
\text { significant effect on } \mathrm{Y}\end{array}$ \\
\hline 3 & $\begin{array}{c}\mathrm{YZ} \\
\mathrm{Ho5}: \mathrm{pl}=0 \\
\mathrm{HaS}: \mathrm{pl} \neq 0\end{array}$ & $t=16,864$ & $t=2.0024$ & Reject H05 & $\begin{array}{l}\text { Z has a positive and } \\
\text { significant effect on } \mathrm{Y}\end{array}$ \\
\hline
\end{tabular}

The table above shows all statistical hypotheses used in this study and the results of their testing. Test number 1 shows the effect of information technology (X2) on job satisfaction $(\mathrm{Z})$ was significant, while test number 2 indicates the significant effect of Information Technology (X2) on employee performance (Y). Test number 3 shows that the effect of Job Satisfaction (Z) on employee performance (Y) was significant.

The results of testing on the effect of information technology on employee performance with job satisfaction as a mediator are as follows:

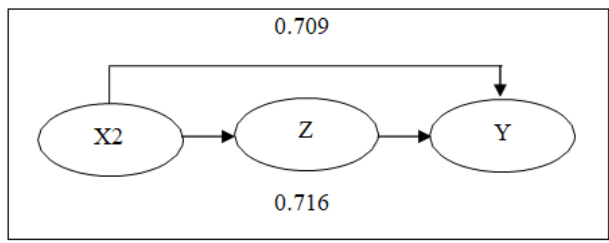

The direct effect of information technology on employee performance in the District Court of Sleman was 0.709 , while the indirect effect of information technology on the performance of employees in the District Court of Sleman (with Job Satisfaction as a mediating variable) was 0.716 . The direct effect of Information Technology on employee performance in the District Court of Sleman was smaller than the indirect effect.

\section{DISCUSSION}

\section{The Direct Effect of Organizational Culture on Job Satisfaction}

The research results explain that organizational culture has a positive and significant effect directly on job satisfaction. The results of this test indicate that the organizational culture given to employees in the District Court of Sleman increases job satisfaction which has an impact on improving employee performance in the environment of District Court of Sleman. Several previous studies also gave no different results [1] stating that organizational culture has a positive influence on employee job satisfaction. In this case, employees who are motivated to be better will increase job satisfaction [8].

\section{Direct Effect of Information Technology on Job Satisfaction}

The research results explain that information technology has a positive and significant effect directly on job satisfaction. The results of this test show that the information technology provided to employees in the District Court of Sleman increase job satisfaction which has an impact on improving employee performance in the environment of District Court of Sleman. A research b [4] found that information technology has a positive influence on employee job satisfaction.

\section{The Direct Effect of Organizational Culture on Employee Performance}

The organizational culture received by employees in the District Court of Sleman has a direct positive effect on the performance of employees with a significance of 0.000 . Previous research by [1] found that organizational culture variables have a positive influence on employee performance. Organizational culture can affect employee performance because it creates a high level of motivation for employees to give their best ability to take advantage of the opportunities in which the organization provides [9].

\section{Direct Effect of Information Technology on Employee Performance}

Information technology received by employees in the District Court of Sleman has a direct positive effect on employee performance with a significance of 0.000 . Another study by [4] found that information technology has a positive influence on employee performance.

The Effect of Job Satisfaction directly on employee performance in the District Court of Sleman, Yogyakarta

Job satisfaction of employees in the Sleman Yogyakarta District Court has a direct positive effect on employee performance with a significance of 0.000 . The results of this study are in line with previous study by [10] stating that job satisfaction has a positive influence on employee performance.

\section{The Indirect Effect of Organizational Culture on Employee Performance Through Job Satisfaction}

Organizational culture has a positive and significant indirect effect on employee performance in the District Court of Sleman with job satisfaction variables. This hypothesis testing was carried out in 2 stages, namely: (1) testing on the effect of organizational culture on job satisfaction, and (2) testing on the effect of job satisfaction on employee performance in the District Court of Sleman, Yogyakarta. The results of both tests are significant and indicate that the organizational culture given to employees in the District Court of Sleman 
increase Job Satisfaction which has an effect on improving employee performance in the environment of District Court of Sleman. This is in line with [5] examining the relationship between organizational culture variables on performance through job satisfaction as an mediating variable. This means that the variable organizational culture affects employee performance, either directly or indirectly, through the Job Satisfaction variable first.

\section{The Effect of Information Technology Indirectly on Employee Performance Through Job Satisfaction}

Information technology has a positive and significant indirect effect on employee performance in the District Court of Sleman through job satisfaction variables. This hypothesis testing was carried out in 2 stages, namely: (1) testing on the effect of information technology on Job Satisfaction, and (2) testing on the effect of Job Satisfaction on employee performance in the District Court of Sleman, Yogyakarta. The results of both tests are significant and indicate that the information technology provided to employees in the District Court of Sleman increase Job Satisfaction which has an effect on improving employee performance in the environment District Court of Sleman. This is in line with [4] examining the relationship between information technology variables and performance through job satisfaction as an mediating variable. This means that the information technology variable affects employee performance, either directly or indirectly, through the Job Satisfaction variable first. Knowledge sharing has an effect on performance employee [11].

\section{CONCLUSION}

Based on the results of the research and discussion, it can be concluded that organizational culture has a direct significant effect on employee job satisfaction; information technology has a direct significant effect on employee job satisfaction; job satisfaction has a direct positive effect on employee performance; and organizational culture has a direct positive effect on employee performance. Employee performance, information technology has a direct positive effect on employee performance; organizational culture has an indirect positive effect on employee performance in the District Court of Sleman through job satisfaction; and information technology has an indirect positive effect on employee performance in the District Court of Sleman through Job Satisfaction.

\section{AUTHORS' CONTRIBUTIONS}

This paper is the result of research conducted by the first author under the guidance of the second and third authors.

\section{ACKNOWLEDGMENTS}

This research was supported by a lot of parties.

\section{REFERENCES}

[1] Sapada, Achmad Faisal A., H. Basri Modding., Ahmad Gani., And Syamsu Nujum. 2017. The Effect of Organizational Culture and Work Ethics on Job Satisfaction and Employee Performance, The IJES, 6 (12): 28-36.

[2] Ilahi, Dede Kurnia., Mochamad Djudi Mukzam., And Arik Prasetya, 2017, The Effect of Job Satisfaction on Work Discipline and Organizational Commitment, JAB, 44 (1); 31- 39.

[3] Soomro, B. A and Shah, N. 2019. Determining The Impact Of Entrepreneur Orientation And Organizational Culture On Job Satisfaction, Organizational Commitment And Employee's Performance. SAJBR. 8 (3): 266-282.

[4] Muzakki, Mukhammad Hilmi., Heru Susilo., And Saiful Rahman Yuniarto. 2016. The Effect of Information Technology Use on Employee Performance. JAB. 39 (2): 109-175.

[5] Hasibuan. Mahdanisa Anggita., Iskandar Muda., And Keulana Erwin. 2019, Effect of Accounting Information System Effectiveness, Information Technology Utilization and Task Fit On Performance with Work Satisfaction as Moderating Variables in the Education Office of North Sumatra Province, JPBAF, 2 (4): 1-11.

[6] Syaifuddin, A. 2004. Research Methods. Yogyakarta: Student Library.

[7] Sugiyono. (2013). Combination Research Methods (Mixed Methods). Bandung: ALFABETA

[8] Farida, S. I., Iqbal, M., Kurniasih, A., 2016, The Effect of Trust and Organizational Commitment on Motivation and Job Satisfaction, Jurnal Kependidikan, 46(1): 121-134.

[9] Jamaluddin, Salam, R., Yunus, H., Akib, H., 2017, The Influence of Organizational Culture on Employee Performance at the South Sulawesi Provincial Education Office, JPIPAK, 4(1): 25-34.

[10] Pawirosumarto, Suharno., Purwanto Katijan Sarjana., And Rachmad Gunawan. 2017. The Effect of Work Environment, Leadership Style, and Organizational Culture Towards Job Satisfaction and its Implication Towards Employee Performance in Parador Hotels and Resort, Indonesia, IJLMA, 59 (6): 1337-1358.

[11] Mayasari, E., Wahyuni, P., Suprapto, H. 2020. The Effect of Organizational Justice and Knowledge 
Sharing on the Performance of Two-Wheeled Gojek Drivers Mediated by Job Satisfaction in Yogyakarta. Thesis. Universitas Pembangunan Nasional "Veteran" Yogyakarta. 